\title{
Comparing Literature and the World
}

\author{
Muhammad Haji Salleh \\ University Sains Malaysia \\ $\underline{\text { mhs0042@gmail.com }}$
}

\begin{abstract}
We compare literary works because we see a lot of uniqueness, differences and everything between them. So we can compare the forms, motives, plots, genres, and functions of each work. Therefore, the sacred duty of Comparative Literature is to blur this separation line and to give them similar status. Meanwhile, we also need to look at the definition of the genre and how this genre is combined and enriched.
\end{abstract}

Keywords- comparative literature, world literature, malay, archipelago.

\section{INTRODUCTION}

Literature develops specifically on village land, city, country and language itself. Literature is also derived from our experience, feelings, situations and needs. Although the language and art of literary works have shown much in common with each other, there are also many differences between them. Meanwhile, in my opinion, literature is the most complete and sophisticated art; it can cross the region and dialect, language and border. And this literature speaks when people from two groups meet. So they were mutually reciprocated, rhyming and storytelling. From their experience we will see similarities and differences.

However, in some forms, such as proverbs and pantun are sailed out of the border, to other islands. We have the impression that the one who brought it is a native of Malaysia. This can be seen in the collection of pantun by Abdullah Munsyi, the Bajau, the inhabitants of the sea who often became a broadcaster of pantun from their area in the Sulu Sea, to the east coast of Borneo, to Flores and even to the eastern islands of Indonesia. And so on, they may be impressed by the pantun or story that the forms are spoken. The good and the beautiful then imitated and adjusted. For example, pantun was created no less than 40 languages - all with specialization and variation.

Tradition in enjoying literary works from neighboring treasures and across the country is something natural and enjoyed for thousands of years. Mahabharata and Ramayana stories are told in dozens of versions and languages from Telugu to Thai, Cham and Viet. In Indonesia, the version of these stories is numerous - from Malay to Sundanese, from Java to Bali, etc. What our ancestors did yesterday and today are comparing literary works to other different languages, consciously or not. In the definition of field and work, a Comparative Literature major at Boston University, explains that,

\begin{abstract}
"A fundamental project of Comparative Literature is to cultivate reading across linguistic boundaries in order to highlight everything that the exclusive focus on a national literature tends to obscure. Studying literature traditionally meant picking an academic department that reflects the nation state on a basically European model. English, French, and German programs each focus on the canons of their respective national traditions. But literature and readers have both always ranged outside the boundaries of one national language. German literature is brimming with the influences of English and French and Italian and Greek and Roman literature and so on. And even writers who knew nothing of one another may show fascinating similarities and differences; a poem by Stéphane Mallarmé and a poem by Emily Dickinson throw each other into startling relief."

However, the traditions of the studies have always left off literatury works from Asia, Africa and the Middle East. These works are often the subject of ethnographic and anthropological studies and are denied as pure literature (such as European and American literature). Therefore, the sacred duty of Comparative Literature is to blur this separation line and to give them similar status. Some of which are examined among others are the expansion of literature, as claimed by Boston University, as the transformation and text of 'across time and space'.

"They explore the connections of literature with history, philosophy, politics, and literary theory. And they study the intersections of literature with other cultural forms such as film, drama, the visual arts, music, and new media. In our increasingly globalized age, translation studies are also an important part of the comparative approach to literature"
\end{abstract}

Thus, the comparable ones are the same and the like, as well as the differences, in language / dialect, point of view, problems, metaphors and also the style of conveying ideas and meanings. From such long explanation from Boston University, therefore, my opinion is quite enough to represent it. 


\section{Literary Background in Malay-Archipelago}

We have tens of thousands of languages in the world; Malaysia has 100 and Indonesia alone is around 700 . Every language then is telling, poetizing, rhyming, singing -then this field becomes very wide and fertile. In addition to acting as entertainers, literary works also serve as a platform for national thinking, emotional and intellectual experiences, and the wisdom of a nation.

It should be noted that literature also specifically stores the traditional knowledge that has now been forgotten, but for thousands of years it has become the basis of science and society's thinking. Literature keeps a variety of sciences - rather than ethno-sciences, rather than ethno-engineering to traditional medicine and architecture. This is the foundation of the nation's genius and platform for its wisdom.

We compare literary works because we see a lot of uniqueness, differences and everything in between. So we can compare the forms, motives, plots, genres, and functions of each work. Meanwhile we also need to look at the definition of the genre and how this genre is combined and enriched -everything from our cultural perspective, which is different from European, North Asian and Western literature.

For example, we can see an underlying cause in the story of Kancil that most likely started in the Peninsula, and it is well known in Sumatra, Java and also the Philippines.

In oral tradition, the literature is fluid, moving in the scene and also the art of its story - and therefore easy to carry everywhere. The stories that have already revealed the plot, the structure and the metaphor the are being added or transformed in places where these works are narrated or sung over again.

We also easily find outstanding talent in our literary genres. From stories, kakawins, poems, news, saga, history, mak yong, shadow plays and spells.

These talents succeeded in producing good and bad literary works. And one of the branches of comparative literature is to trace their talents and geniuses. Meanwhile in the larger study, we will be able to see the literary greatness of a tribe and nation.

In the higher rank is poetic or literary theory for every tribe, and language. I tried it in Puitika Sastera Melayu (The poetic of Malay literature) and found many that had not been described before and by that can illustrate the concept of the beauty of the work, the function of the author and the work, the concept of the audience and the good literary language.

In this way we can examine the thinking that grows in literature, views of life and human values are good and complete, and also the human archetypes in this part of the world.

We also, like I mentioned before, can study the various genres of our literature, and show its uniqueness - and finally as in the Malay literature, how these genres are mixed in for the best impression in oral literature and even in written works.

In an era of clichés, the act of stating that 'we live in a global world, and without borders' - is just a cliché statement with zero meaning. We also forget the world we are referring to. Is it in the world that we are only buyers of trash goods, and consumers of obsolete ideas?

Actually, this world is so complex, diverse, weird, thoughtful and often annoying. However, there are such quality, diamonds, and gems on the rhythm and singing of its voice.

Therefore, we must immediately establish where our place is in this world. I want to see us as citizens who contribute and help to constitute the country with our uniqueness.

That is the title of the session given to me: "language and literary comparison". So, I went from one situation to another and now we also need to take a break to discuss it.

Our world painted and built by language. All of human's parts of lide, colors, all kinds and lines of mood, all of which are shaped by language. It is also not forgotten that paintings and fine art have also for thousands of years painted people and their lives. However, in reality, the language is the most complete as a means of painting and drawing.

The language we use today is characterized -letters, alphabets- not forgetting the meaning and sounds, voice and rhythms. Formerly, in early Malay belief, the world rests on the back of a cow. However, the cow was tired enough to bear it. So sometimes the cow shook her head - then there was an earthquake. Today, a series of letters and writings replace the buffalo es burden. In the past, there were hundreds of characters and millions of books. In the future, we also see the world above the characters, letters, and billions of computers. Language then becomes a tool for creating literature, which is considered a form of the most subtle, complete, beautiful and meaningful expression of a nation.

I was fortunate to be given trips and bridges to some worlds, as students and young and old lecturers. I was given a bridge to cross and enjoy the bits of expression of the nations that exist there. So I chose comparative literature as my research field. And I do not regret that in it there is a language adventure, music and also the idea of a chosen human being. I was also given the opportunity to connect and link these experiences and explain in front of the audience. I am grateful, and hope these bridges will be tried quickly too. 
Although some of us now are less comparable, for some reason - but many of our old ancestors did it before. Malay-language authors learn from stories around and across their region. Then quote Panjies story and turn into a good prince in Malay. That is why there are so many stories entitled Panji in Malay, and probably more in their native language.

In addition, we enjoy the stories of Mahabharata and Ramayana, initially, most probably through Javanese. Persian Work in the Middle East is brought by Bayan Budiman and Abu Nawas to our beaches and villages; Arabic works are translated into Hikayat Amir Hamzah, Hikayat Muhammad Ali Hanafiah, Hikayat Nabi Bercukur etc., in some languages in our archipelago.

Takdir Alisjahbana and Amir Hamzah got the effects of Dutch and European literature being taught in their classrooms, while Chairil translates Marsman and Chinese poetry. Sapardi studied English literature and Goenawan learnt French and English works. They walk on bridges of knowledge to other continents. In Malaysia, Sanskrit, Persian and Arabic literature also leave their footprints.

When England colonized a place, British literature also came through the imagination of their young author; including Shakespeare, Swift and Dickens, Keats, Lawrence and Larkin. French literature is enjoyed through Dumas and Hugo 's translations into English. Before we forget that the most important attraction in the literature is its creative element - in oral and scritural form. In addition, literature provides space for criticism and theory, which is considered an important path to study the comparing literature. So there are poems and novels also plays, in addition to critics and theories and ideas about beautiful and significant works.

$* *$

I would like to enter into every part and witness the greatness of world literature. In my life, this dining table is so big, fun, and fast. Let me describe them one by one in this discussion.

\section{METHODS}

\section{Important terms in Literature}

Since literature develops through language and place then many terms grow in language and have a separate meaning from other languages. For example 'author' in English, or 'auteur' in French and Dutch. In our culture in the Malay Peninsula and the Malay worlds, there are so many terms used in this European term: masterminds, storytellers, pekonon, copyists as well as translators who adapt and narate. They make up stories in various ways and habits.

The puppeteers of a wayang kulit show composed and directed the wayang kulit by themselves, and they may also carve their statues. A storyteller will adjust the length of the show; and so does the aspect of the story with its audience context. There may be a section highlighted in a performance, and reduced in other performances.

Similarly, the terms for the audience who once also referred to as ‘hearings session”, ,readers ${ }^{\text {ee }}$ sessions, etc.

The terms for the form are quite original and unique - such as lyrics, poems, proverbs and axioms. The forms are much different from iambic pentameter, sonnet or free verse.

Legend, history (royat), tale and story, are also in form of narrative prose, which is no less poetic. Our poem is different from Arabic poetry, and our legend is dissimilar with the novel of Europe or Japan.

\section{World Literature for the Author}

As we watch American films, Hindustan, China and Korea, we indirectly cross the border of the language and culture. So we have stepped on, and walked into the world of literature. In a comparative literature, we are also invited to compare among literary theories, works, and also between genres - for example Shakespeare and film, and literary functions and music.

For me, a great nation is one who diligently reads and has a large and good library. In reading, we learn and in learning, we borrow. I cannot describe how much benefit from reading the world literature. For writers, we have mentioned that there are thousands of good examples that we can quote. We can also gather their wisdom and also explore their conscience. It is the wisdom that gives life and extends the steps of a nation. The wisdom offered by those literatures is not easily quoted from sociology or anthropology. Literature offers a picture of life with its feelings along with prejudice and honesty. In comparison to literary paintings which are more complete, layer, and perspective will give us more in point of view and life through the characters.

However, we do not just read the written text, because most of the sophisticated world literature exists in oral form. In our world, in Southeast Asia, shadow puppets, narrative storytelling, makyong and dozens of other forms are practiced in spoken language. So, while we got benefit from written literature, oral literature is also no less thoughtful and beautiful. For this purpose, we may enter into oral literature of Polynesian, South American native, together with Africa, which we now know little about.

Therefore, an author should get an example from the best authores style and thought in his/her own language. A young writer needs to read poems from Amir Hamzah, prose of Pramoedya Ananta Toer and Subagio Sastrowardojo, also Baha Zain and Anwar Ridhwan to Latiff Mohidin. From Brunei, there are some works from Muslim Burmat and Singapore has Isa Kamari and several other names. 
But there are many more out there apart from our vast language and culture which can also help us in our complicated and abstract authorship"s work - which we call the creation of literature.

Generally I can agree with George R.R. Martin, in A Game of Thrones, who said, "... a mind needs books as a sword needs a whetstone, if it is to keep its edge."

For some authors, the other authors are also the sharpening stones. To our local authors can also add the world's greatests; Neruda, Marquez, Lorca, Shakespeare, Lawrence, Joyce, Murasaki Shikibu, Yoshimoto, Basho, Kawabata, and Oe.

From China, there are Nobels laureates such as Mo Yan and Ba Jin and from their past history - Po Chu-I and Lu Xen; Korea give us Kuo Un, and India offfer R. Tagore and Salman Rushdie. Turkey present the name Jalaluddin Rumi and Orhan Pamuk, and France inherits us Le Clezio, Baudelaire, and Camus. England contribute big names like Lessing (Doris), Keats, Auden, T.S. Elliot, Frost and Dugan; Russia with Dostoevsky and Tolstoy; and Africa with Soyinka and Najib Mahfouz.

In our language, many have been forgotten: pantun, proverb, Sulalat al-Salatin, and Hangul Hikayat, the four peaks of our literary genes.

According to Orhan Pamuk, from the great author, we can learn about talent. It is quite real - but sometimes from the common author, we can also learn some examples such as terms, poetry creations and plots. He added that we must: think big, think bigger and biggest. This ,think bige can also learn from the big authors.

Thus, good works teach us to recognize human beings and cultures through their language aesthetics and great ideas.

\section{What can we compare?}

\section{FINDING AND DISCUSSION}

First, the insight they bring -through themes, reflections, perspectives on humanity, that is about humanity, like us, which is very difficult to understand from outside, but sometimes easier from within and the authores heart. I learned from literature many things that make human beings become noble, self-righteous, thoughtful and wise.

Many themes are universal or collective in nature - because the author is still a human - is still the same though different backgrounds, though it is changed by the environment and also the contents of the heart and also character. In their life, they experienced many things which then created important themes of their creation:

\section{Love}

Love is a classic theme in all languages. In Bengali, especially in poems from Tagore and A. Rahman (in English translation), some of the metaphors used are clearly universal - moon and flowers, trees and lakes. Just as in Layla Majnun, Gita Govinda, Romeo and Juliet, and Panji.

For modern times, we may say Twenty Love Poems and a Song of Despair. The poem is always a beauty, however, there are lines that not merely sweet, but half-sad, lonely and desperate. The situations and feelings are dramatized for narrative point. His feeling reached the hyperbole, and the passion is poured out of his talent.

As a comparative literary practitioner, we must seek, define, and describe the treatment and feeling of affection, a very basic feeling and deed. Love, affection, romance, and lust, often march in front of us, in front of the reader's eyes and the ear of the listener, and shadows behind the blind dreams of the actors. This love can be lonely or sad, happy or lively, but often present a hope in the end of the story. The scene always comes vaguely between reality and dreams, between the shadow and the reality. Although there is a metaphorical area of traditional love, there are also new metaphories that are also beautiful and admirable. There are many more love themes that we can explore and highlight and try to compare with our literature.

In Malay literature, I tried to track the form and levels of romance movement. I found 21 imaginable stages in traditional love stories -from the dream or shadow of the lover to be met, up to lurking the princess, to love, to be married and even a farewell. My study was based on Stephen Kern, The Culture of Love: Victorians to Moderns (1992) which saw 18 stage of love in Viktoria's literature.

We can further compare the process or treatment of romance in Korean, Javanese or Maori literature. All is always possible and I feel very charming.

\section{Younger Age}

The second theme often repeats is the young experiences which often bring nostalgia and old memories. I am most impressed by Muhammad Radjab's autobiography, Semasa Ketjil di Kampung, not only because of it has clear style, but his experience is quite similar to my experience in the village, and with many other readers.

Novels such as Tom Brown's Schooldays by Thomas Hughes, Huckleberry Finn by Mark Twain, and I am a Cat by Natsume Soseki, are among the works of the same kind that long ago refer to the reader for the painting of the authores childhood or other characters. 


\section{Nature}

While many authors do not specialize in nature and the natural environment, many are touching the natural impact on a person or society. In another article I mentioned, with earth, rivers, seas and weather/seasons like this, then the plants and living things appear and grow. All of this helped to create a view of his life, including the nature.

Therefore, humans indirectly become observers who signify and recognize phenomena or habits that apply to their nature. For example he captures the following natural attributes, as enshrined in this proverb:

There is a cane, there is a thorn

coats must be floating, the stone is drowned.

Big wood, big branch

And

Which sea is silence, which land does not rain?

The wind blows, the season changes

The wind is swirling, the waves are sailing

Humans must recognize their nature in detail and comprehensiveness so he can live safe and comfortable. He has to recognize the fertile land, suitable wood for the hall or building outside the roof.

For their food and health, they are obliged to recognize the type of plant that can provide energy and nurture a healthy body. So they became ,nature-wise, environment-wise, weather-wise". After that, they must recognize the character of the plant and also the enemy of the plant - from grass and weeds to worms, birds and blight.

After experiencing these natural experiences, they became a member of nature who existed outside themself, outside their home. Sharp watchers will also be able to understand fate, fortune, hatred, irony and other traits imagined by the way and nature of plants, animals and humans. All this can be read in the natural landscape. This knowledge finally helps people for living.

Kayu pulai di Koto Alam,

Batangnya bersendi-sendi

Kalau pandai dalam alam,

Patah tumbuh hilang berganti.

Timberwood in Koto Alam,

The stems are jointly

If you are good at nature,

Whatever broken will grow back, whatever lost will be replaced.

Finally, because the views of the Malays are created by a positive relationship between the inhabitants and their nature then there are also some concepts that may be called as views of nature that resemble the Malay philosophies of nature.

This relationship can be considered harmonious, especially since this world is more supportive and helpful to humans in their lives. This view is also quoted from empirical knowledge, from individual lives or treasures of the community"s experience.

George Gordon Byron (1967) painted the relationship between man and nature;

There is a pleasure in the pathless woods,

There is a rapture on the lonely shore,

There is society, where none intrudes,

By the deep sea, and music in its roar:

I love not man the less, but Nature more.

Henry David Thoreau, in Walden, such as repeating the philosophy of Malay-Archipelago nature,

"Live in each season as it passes; breathe the air, drink the drink, taste the fruit, and resign yourself to the influence of the earth."

Naoki Higashida also detects natural influence on autistic children,

When we look at nature, we receive a sort of permission to be alive in this world, and our entire bodies get recharged. However often we're ignored and pushed away by other people, nature will always give us a good big hug, here inside our hearts." 
Forty thousand poems, modern and old-fashioned was written about nature which is an environment of human, beautiful, help human to life and to grow. However, nature also can destroy human, their house and village.

\section{Adventure}

Besides exploring the natural environment, humans also always want to know what is out of their village or country. In the oral story, the beginning words often mention:

"Climb up and down the hill, we will find the lake..."

It just just a few words, described the deeds of wandering in the jungles and valleys, and the discovery of things or stuffs that have not been seen before.

"Why do people travel?"

Among the goals is to explore the world and new space -as a farmer, ruler or thinker. In these genres, the author also tries to explore space in him/herself - values, feelings and thoughts.

There is also another purpose that we should mention: to discover the truth of the self, or the truth that is not given by his/her life, somewhere. Then he/she had to go outside the boundaries of the village and country, and try to find the truth that has opted out, there.

The 'comeback home' journey from our people is a very interesting and adventurous travelling and in it, many can be found the meaning of life that has been separated from the village or the homeland. This is also a sentimental journey, for nostalgia, as well as clearing and balancing the reality of new place and hometown.

\section{War and Conflict}

War has always been a black spot in human civilization; through banal or symbolic paintings, outside or inside a human being. War was never finished. Defeat and victory are interchangible - which is in the end, there has never been a winner. War theme is often related with power theme. War is the means of control over other people or other countries. It is often emphasized in a conflict, the contrast between good and evil, as the value of two opposing characters or groups.

A series of Good Rama must overcome the evil Rahwana character. Therefore, the war is about the two values - very conflicting, but sometimes there are also overlapping and dilemma. Here, we find the irony of the war. In the old Malay story, there is a good princess, captured by the evil garuda or Human character such as Patih Kerma Wijaya (in Hikayat Hang Tuah), who planned the downfall of Hang Tuah, the main hero of Malay literature.

In English literature, Lady Macbeth, the wife of a nobleman is very captivated by power. He arranged for Macbethes enemies can be killed and the crown can be controlled. This power never last long.

However, there is more philosophical thought found in Malay proverb: when shepherds quarrel, the wolf has a winning game. This is the irony of human civilization; this is the irony of power and government. With his philosophical work today, it is not surprising if Ismail Kadare from Albania with his work The Sieze is considered one of the best authors in Europe today. Previously, For Whom the Bell Tolls by Hemingway records the impact of a civil war in Spain, which also emphasized that victory also overthrows the winner.

Sulalat al-Salatin also tells about the inexorable resistance with Melaka's enemies -at first place with Siam, afterwards with the kingdoms in Sumatra and finally with the Portuguese in the Kampar River.

\section{Plot and story line}

Life is a number of episodes or stories. Good story based on interesting plot; it sometimes is taken directly from real life; it sometimes is altered to bring the author's conclusions about something or a journey of life.

So, we can see that there is a narrow story -where the journey goes to just one destination. For example, travel back to the roots of life to find ourself. At the end of the search can be found, but also on the contrary, there is also disappointment.

There are other three-story stories -especially about love, war and friendship stories.

Many stories have split the plot - each carrying a phase of life or story. Occasionally, the end has a twist suprise ending.

\section{Poetic Language}

One of the things that is always investigated is the language tools used by the author. Like someone $\mathrm{s}$ clothes, the language is also worn by the author with a taste, with its character and its aesthetics. There is a sublime or plain in form, some of which show new experiments.

For the perspective of an author's language, metaphors often take on important position; (perhaps) it because the metaphor is beautiful, philosophical, and imagines more sophisticated talent.

Traditional authors take their metaphorical demonstrations from nature -usually from oceans, rivers, swamps, forests, hills, mountain moons and stars. 
New poems explore further the language of the view, very different from traditional listening languages. With the advent of the graphics world, then the poetry is increasingly visualized. The metaphor also turns into a reference group to the city, economy and even cyber world.

The study of metaphors at a more sophisticated level is to search and compare it between authors or languages. In the field of poetry, the metaphor is considered to be the highest achievement of a poet. By comparing, we also focus on the success of an author who is cleverly imagining a world behind the meaning, while still presenting the world ahead of him. There may be seen the quality of a creation, a poet's way of thinking and how he sought a replacement for a rough reality.

Experiments with language have always been a major attraction in the study of literary comparative. For example, a language experiment in Finnegan's Wake, which further promotes ,stream of consciousness ${ }^{\text {ee }}$ experiments. But, unfortunately it is a quite extreme and often cannot be enjoyed by its readers.

While earlier works also by Joyce, Ulysses, is easier and more affordable by readers. Meanwhile, poet Wales, Dylan Thomas, in contrast to R.S. Thomas -who is also from Wales, the first is more solid and dramatic language; the latter can be called as a minimalist one.

In the Malay-Archipelago, we are also often impressed with the sophisticated language brought by Chairil Anwar, Baha Zain and Roslan Jomel.

For other studies, we can also compare the language of pantun and haiku or and comparing Malay and Arabic poetry.

\section{Form and Structure}

Many things can be discussed in form and structure in traditional and new language of a literature. Age changes the style and preference of readers. As a result, there is a stream that changes this direction -for example expressionism, romance, and absurdism.

The composition of the traditional story is various -from a plain statement, to a world of dreams and fantasies and that exist beyond the daily reality.

Furthermore, experiments were also made to imitate the intuition of the mind and thought -diving into someone too modern, because according to Marquez, this is the way his grandmother tells something to him. a warning.

In early Malay stories, dreams help the characters in imagining their future. Dream brings a purpose, as well as

There are dozens of experiments that can be started relating to the structure of a novel. For example is using chapters to divide scenes or events. This is very common and helps us to understand the story of the work. However, there are works like Finnegan's Wake, which does not use division of chapters, but also without a coma or a dot. It is strange for his reader, but Joyce wants to take the reader into his cluttered mind, which is not separated. This is not very strange because this is how old Malay literature is written in thousands of scripts.

There is also a poem, which is different from a prose, which is also has various structures -from sonet to iambic pentameter, from couplet to quintet, from ballad to epic/long poem.

Traditional literatures such as lyric and poetry is very interesting -especially pantun. This form is quite old and has a variety of variations, from the two pieces of pantun, to four, ten and twenty two. There are also other variations, namely pantun Alif Ba Ta, rejang pantun, Bujang Membilang Malam, tied pantun, mukun, series pantun, etc.

In Japanese literature, we can also see the development of basic form of haiku, which is 3 lines with syllable number 5, 3, 5 becomes renga which takes place from two parts and must be written by two poets, and after that became increasingly fragmented into a new poem and a graphic.

\section{Narrative}

How to set up a story is also determined by its time. For example, oral stories often use aide-memoirs (reminder tools) so that listeners do not forget about the storyline, the place and the characters. One of the ways is the deduction -which helps the listeners to re-call with their references.

From a traditional style, we see a lot of developments when we enter modern or post-modern period. Names such as Sutardji in Indonesia and Ghapar Ibrahim in Malaysia bring some changes. Sutardji reconstructed the temporary sound element for his mantra impression, while Ghapar Ibrahim uses sound as a rhythm and even a narrative form. So, there is no longer any element of time in a linear narrative or neatly organized stream of time.

In Hujan Pagi (Morning Rain) by A. Samad Said, sometime past-time was given the same plot as the present day, in a simultaneous way of thinking in the stretch of stream of consciousness. So, episodic form or arrangement is no longer available.

Furthermore, the genre may also be supplemented by the author and mastermind for specific needs. So, in traditional prose there are often gurindam and pantun. In several hikayat, the story is supplemented with some explanations about how to make a husband more affectionate to his wife, how to keep a good smell of breathe, and last 
but not least is how to make love. Such advices are found in Hikayat Isma Yatim. However, this Hikayat is also proposed how to make a garden. This is what I consider to be a mixed genre of writing.

In Malay literature, this strange taste is very much, which is very rare in European literature. In our literature, especially, Wayang Kulit, has elements of drama, art of engraving, humor and religion at once; there are also spells, cursings and pantun and songs. Normally, in a story there is also a song, in a song there are also feelings and affections together.

\section{Aesthetics, the concept of literary beauty}

Although not every nation has its own aesthetic, our literature can show its uniqueness, compared to other literature. Malay aesthetics are closer to the concept of minimal expression, especially in the iconic art, pantun. There are sounds and voices, also the mockeries and the world of shadows before the actual meaning is conveyed. In the concept of Malay beauty too, sounds and voices are concerned -and play or speech enjoyed through these sounds and voices. In this case, pantun shows some similarities with haiku, renga or tanka Japan, which is also looking for beauty on the appearance of the image and the implied meaning.

In India, the concept of Indian art performances and practices is once described by Bharata, in his Bharata Natyashastra, which attempts to cover all areas of Sanskrit plays, probably in the first century until 3 BCE. In his opinoin, performance not only should demonstrate body movements, hands and feet, but also faces, eyes and other body parts of the character. Cultural relations with India embody the effect to Balinese drama and ritual performances.

\section{CONCLUSION}

Thus are some aspects and angular comparison of literature which I think can be accessed by Comparative Literature scholars in Malaysia and Indonesia. There is a lot of knowledge to learn from literary culture across our fence -from the concept or the literature itself to the fine language and the beauty of the works.

Many of our authors - since long ago, have crossed the border of language and region to bring the beautiful and unique of other's literature and then provide another angle or face to our traditional literature. Furthermore, our literature is evolving with the response to these new and unique elements. We have mentioned the names such as Chairil Anwar, Sapardi Djoko Damono, Goenawan Mohamad and Baha Zain, Anwar Ridhwan, and perhaps the author himself who familiar with foreign literature. However, they still remain good authors of Indonesia.

Colonialism blocks and narrows our authorship and its possibilty for several hundred years. I believe that literature beyond our borders, replacing what Cesair said and reiterated by Edwin Thumboo, extraordinary possibilities

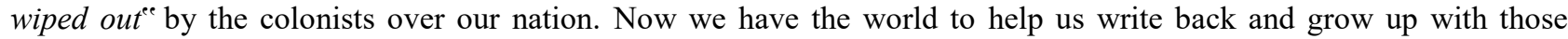
examples.

\section{References}

Auerbach, E. (1993). Literary language and its public. Princeston: Princeston University Press.

Bennett, B., Jeff, D., \& Sastendra N., (eds). (1996). Crossing cultures. London: Skoob.

Dewan Bahasa dan Pustaka. (2000). Kurik kundi merah saga. Kuala Lumpur: Dewan Bahasa dan Pustaka.

Hikayat Isma Yatim. (2017). Muhammad Haji Salleh ed. Kuala Lumpur: Yayasan Karya Agung.

Lanang, T. S. (1997). Sulalat al-Salatin. Muhammad Haji Salleh, ed. Kuala Lumpur: Yayasan Karya Agung.

Miner, E. (1990). Comparative poetics: an intercultural essay on theories of literature. Princeton: Princeton University Press.

Nasaruddin, M. G. (2009). Traditional Malay theatre. Kuala Lumpur: Dewan Bahasa dan Pustaka.

Neruda, P. (2004). Dua puluh sajak cinta dan sebuah lagu kecewa, terj Muhammad Haji Salleh dan Zakaria Ali. Kuala Lumpur: Dewan Bahasa dan Pustaka.

Salleh, M. H. (2000). Puitika sastera Melayu. Kuala Lumpur: Dewan Bahasa dan Pustaka.

Salleh, M. H. (2018). Pantun: Poetry of passion. Kuala Lumpur: University of Malay Press.

Sweeney, Amin P.L. (1972). The Ramayana and the Malay shadow-play. Kuala Lumpur: Universiti Kebangsaan Press. 